ISSN:2656-4270 (Online) 1410-4466 (Print) Accredited by Ministry of Research, Technology, and Higher Education with the ranking of Sinta (S4) SK NO.28/E/KPT/2019, 26th September 2019
Buletin Penelitian Sosial Ekonomi Pertanian Fakultas Pertanian Universitas Haluoleo

2020:22(2):82-89

http://ojs.uho.ac.id/index.php/sosek

doi: http://dx.doi.org/10.37149/sosek.v22i2.14241

\title{
THE RATIO OF ADDED VALUE TO MARGINAL LAND USE OF EMBANKMENTS IN WISATA AGRIBISNIS
}

\author{
Hartati $^{\left.{ }^{*}\right)}$, Ahmad Muhlis Nuryadi ${ }^{1)}$, Sitti Rosmalah ${ }^{1)}$ \\ ${ }^{1}$ Department of Agribusiness, Universitas Muhammadiyah Kendari Southeast Sulawesi, Indonesia
}

${ }^{*}$ Corresponding author: hartati@umkendari.ac.id

To cite this article:

Hartati, H., Nuryadi, A., \& Rosmalah, S. (2020). The Ratio of Added Value to Marginal Land Use of Embankments in Wisata Agribisnis. Buletin Penelitian Sosial Ekonomi Pertanian Fakultas Pertanian Universitas Haluoleo, 22(2), 82 - 89. doi:http://dx.doi.org/10.37149/bpsosek.v22i2.14241

Received: September 22, 2020; Accepted: January 25, 2021; Published: January 28, 2021

\section{ABSTRACT}

The main activity of pond land in Wisata Agribisnis is the cultivation of milkfish. However, to maximize the use of pond land, pond farmers plant dragon fruit plants to add value to land management. This research aims to analyze the value-added ratio on marginal land. This research method is a case study of qualitative and quantitative data of marginal land use in Wisata Agribisnis. Quantitative data are analyzed with income analysis and value-added commentary. Qualitative data describe the marginal land use of embankments. The research results of dragon fruit planting in the marginal areas of pond embankments showed: 1) dragon fruit plants do not pollute pond water, this is because the structure of dragon fruit plants is similar to cactus plants, 2) full sunlight in ponds is very suitable for dragon fruit plants, 3) plants dragon fruit is very tolerant of brackish water, 4) the taste of dragon fruit remains sweet in root conditions close to brackish water, 5) dragon fruit plants continue to bear fruit even though planted in marginal land at the embankments of the pond. The research results on marginal land use of pond embankments by planting dragon fruit plants added a value of IDR17.302.857, with a ratio of $85 \%$. Pond farmers can take advantage of the marginal land of their ponds by planting dragon fruit plants.

Keywords: dragon fruit; marginal land; milkfish cultivation; value-added

\section{INTRODUCTION}

Marginal pond land managed by pond farmers located in the coastal area of Kendari City carries out milkfish farming activities. This routine has been in place since the 1980s. The pond land in question is the pond land as a whole, including the pond embankment utilized to the maximum by pond farmers. In carrying out their daily activities, pond farmers experience several problems. This is due to the decreased productivity of the pond land-reduced productivity of pond land due to various issues. Pond farmers feel the effect of the decrease in productivity of pond land with the decline in income received. For that, there is a need for ways to maximize the utilization of embankment land in increasing the income of embankment farmers to provide added value. According to Manulang (1990), planning and implementing productivity activities by allocating resources is value-added. Top management of pond land by applying land use technology will provide added value that can support the lives of pond farmers.

Pond farmers in Wisata Agribisnis apply dragon fruit crops to use marginal land of pond ridges. Dragon fruit is the choice of pond farmers in solving problems. Various considerations determine the selection of dragon fruit plants. The primary concern is intended to increase and or augment the income of embankment farmers. The increase in revenue of pond farmers is an added value obtained by pond farmers by increasing activities around the pond land.

The added value obtained by pond farmers is the optimization of marginal pond land utilization in Wisata Agribisnis. Added value is the part that pond farmers get in improving their quality of life. Pond farmers will enjoy the acquisition as part of their innovative work to maximize land utilization. The amount of added value obtained increases the income of pond farmers. It is part of the satisfaction of pond farmers for the additional work done-utilization of marginal land as an effort by 
pond farmers to support their lives to be better. The experience of pond farmers in utilizing marginal land is a solution in solving the problem. Hartati et al. (2017) stated that experience contributes to farmers' ability to solve problems and manage risk.

This study aimed to analyze the ratio of value-added utilization of marginal land dike embankment to increase revenue. On the other hand, the utilization of marginal land is also an attempt to capture the added value of the overall effort to overcome the problems of farmers in earned income. To obtain added value from the pond land, pond farmers maximize the utilization of their pond land by doing dragon fruit cultivation in the pond embankment while still cultivating milkfish and shrimp as the main activity. Hicks (1995) states that activities with the characteristics of a) increasing added value, b) producing products that can be marketed or used or eaten, c) increasing storage capacity, d) increasing income and profits of producers are agro-industrial activities. Agro-industrial activities are a process of adopting technology.

Pond farmers cultivate dragon fruit crops in the marginal areas of their ponds through a process of thought, experimentation, and mature consideration. The decision to adopt dragon fruit plants to be planted in the pond land through the thinking that dragon fruit plants are resistant to heat conditions by the tree resembles a cactus tree. The choice of dragon fruit to maximize the use of pond land is the right choice. The efforts of pond farmers are adopting technology according to the conditions of the pond land owned. Optimal land use by planting dragon fruit is a solution that farmers implement to increase income.

\section{MATERIALS AND METHODS}

The research was conducted on marginal pond land in Kendari City Wisata Agribisnis from late March to early May 2020. Wisata Agribisnis was selected as the research location, considering that Wisata Agribisnis is one of the ponds that utilize the pond land by planting dragon fruit crops. The sampling technique used a case study on the ground of milkfish and shrimp farms and used the land of the pond by planting dragon fruit plants. The variables measured in this study are fixed costs and variable costs of pond cultivation, variable costs and fixed costs of dragon fruit crops, price, production, and labor. According to Mubyarto (1995) that production costs are divided into two types, namely fixed costs and variable costs. Data sources in this study use primary and secondary data. This study uses one year with three harvests by using interview and observation data collection techniques. The research also uses descriptive analysis to describe the condition of the pond land. It uses simple statistical analysis of graphs, tables, income analysis, and the Hayami value-added analysis model (Hayami et al. 1987)

Table 1. How to calculate the value-added of ponds in a year

\begin{tabular}{lcc}
\multicolumn{1}{c}{ Variable } & Value & Method of Calculation \\
\hline Output, Input, and Price & 1 & \\
Milkfish production (kg) & 2 & \\
Milkfish seeds (1 package = 1.000 fish) & 3 & \\
Workforce (org) & 4 & $1 / 2$ \\
Conversion factor & 5 & $3 / 2$ \\
Labor Coefficient & 6 & \\
Milkfish Production Price (IDR/kg) & 7 & \\
Labor wages (IDR/persons) & & \\
\hline Receipts and Profits & 8 & \\
Price of milkfish seeds (IDR/kg 1 package = 1.000 fish) & 9 & $4 \times 6$ \\
Other input contribution (Dragon fruit cultivation) IDR/kg & 10 & $10-9-8$ \\
Milkfish Production Value (IDR/kg) & $11 \mathrm{a}$ & $(11 \mathrm{a} / 10) \times 100 \%$ \\
Value added (IDR/kg) & $11 \mathrm{~b}$ & $5 \times 7$ \\
Value Added Ratio (\%) & $12 \mathrm{a}$ & $(12 \mathrm{a} / 11 \mathrm{a}) \times 100 \%$ \\
Labor compensation (IDR/kg) & $12 \mathrm{~b}$ & $11 \mathrm{a}-12 \mathrm{a}$ \\
Labor share (\%) & $13 \mathrm{a}$ & $(13 \mathrm{a} / 11 \mathrm{a}) \times 100 \%$ \\
Profit (IDR/kg) & $13 \mathrm{~b}$ & \\
Profit rate (\%) & & $10-8$ \\
\hline In Return for Production Factor Services & 14 & $(12 \mathrm{a} / 14) \times 100 \%$ \\
Margin (IDR/kg) & $14 \mathrm{a}$ & $(9 / 14) \times 100 \%$ \\
Labor compensation (\%) & $14 \mathrm{~b}$ & $(13 \mathrm{a} / 14) \times 100 \%$ \\
Contribution of other inputs from dragon fruit cultivation (\%) & $14 \mathrm{c}$ & \\
Capital owner profit (\%) & & \\
\hline
\end{tabular}




\section{RESULTS AND DISCUSSION}

The utilization of the pond embankment land by planting dragon fruit plants makes the pond look beautiful to look at, and this is because dragon fruit plants have an attractive shape and color. This concept can be developed for tourism needs according to the planning of Wisata Agribisnis. Hartati et al, 2018 stated that the idea with the design of a tourism-based management model is expected to be one of the alternative solutions to meet the needs of the people of Kendari on the one hand and business development for pond farmers on the other. The dragon fruit plant is also a plant that is very tolerant of sunlight and brackish water. In this condition, the dragon fruit remains sweet and dense even when planted in the marginal land of the embankment.

Milkfish farming is carried out three times a year. The costs used are fixed and variable, consisting of labor, nener, seeds, and fertilizers. At the same time, the fixed cost consists of nets, cork, machete, hoe, and scope. Similarly, the cultivation of dragon fruit crops is an additional activity to maximize the use of marginal land. Kuswadi (2008) said that fixed cost expenditure is usually calculated over time, generally called period cost. In fact, for relatively long periods, fixed costs can change at any time. The lower the fixed cost, the greater the profit. In line with the above statement, Padangaran (2013) said that fixed cost (fixed cost) is a cost that amount remains the same even though the volume of production fluctuates. Fixed costs are usually indirect costs (overhead costs), which are costs incurred not based on the amount of output or the sales volume size. With the use of production costs on pond land in Wisata Agribisnis, the total costs for milkfish and dragon fruit cultivation consist of the production costs of the first, second, and third months can be seen in Table 2.

Table 2. Cost, production, and income of pond farmers in Wisata Agribisnis

\begin{tabular}{lrrrr}
\multicolumn{1}{c}{ Description } & Cost 1 & \multicolumn{1}{c}{ Cost 2 } & \multicolumn{1}{c}{ Cost 3 } & \multicolumn{1}{c}{ Amount } \\
\hline Milkfish Cost (IDR/year) & 980.000 & 1.250 .000 & 1.365 .000 & 3.595 .000 \\
Dragon Fruit Cost (IDR/year) & 150.000 & 175.000 & 285.000 & 610.000 \\
\hline & Harvest 1 & Harvest 2 & Harvest 3 & Amount \\
\hline Milkfish Production (kg) & 192 & 182 & 197 & 571 \\
Dragon Fruit Production (kg) & 32 & 37 & 31 & 100 \\
Price of Milkfish and Dragon Fruit (IDR) & 25.000 & 25.000 & 25.000 & \\
Milkfish Receipt (IDR) & 4.800 .000 & 4.550 .000 & 4.925 .000 & 14.275 .000 \\
Dragon Fruit Receipt (IDR) & 800.000 & 925.000 & 775.000 & 2.500 .000 \\
Milkfish Income (IDR) & 3.820 .000 & 3.300 .000 & 3.560 .000 & 10.680 .000 \\
Dragon Fruit Income (IDR) & 650.000 & 750.000 & 490.000 & 1.890 .000 \\
\hline
\end{tabular}

Source: Primary Data, 2020.

Based on Table 2, it is known that the cost used is relatively small and is the minimum cost according to its use. This is because pond farmers produce in relatively small quantities adjusted to the capacity of the land. In connection with this, Soekartawi et al. (1986) argue that farmers can control production costs in their businesses but cannot regulate the price of the commodities they sell or give value to those commodities. These prices are determined by various factors that exist outside the farm. If other circumstances do not change, the farmer must reduce the cost per unit of the commodity produced if he wants to increase the net income of his business based on the principle of cost analysis. Samuelson and Nordhaus (2004) say that companies should pay full attention to costs and manage them well because every penny of costs will reduce its profits. The use of fees that can be minimized will increase revenue. Furthermore, Siagian (2009) said that the price is a payment burden that will reduce income on each use.

According to Table 1, the total production of milkfish is higher than the total production of dragon fruit. Milkfish production in the pond land of Wisata Agribisnis varies with each harvest period. Although each harvest its variation is relatively stable. The data is data of three crops in a year. Pond farmers also pay attention to the time when the community's needs for pond production. There are times when the price of milkfish becomes more expensive. This is following the results of research Hartati, (2015). Farmers will respond to the community's needs at a specific time and increase livestock maintenance. This also happens in the production of dragon fruit. However, the production of dragon fruit is relatively small compared to the production of milkfish. But it can help pond farmers to meet their living needs. Dragon fruit plants planted in the mine ridge have a relatively distant planting distance, about 4 - 6 meters. So for efficient land use, it is still necessary to insert dragon fruit plants between the planting distances. If pond farmers do this, it will increase dragon fruit production. one input does not cause a change to the other input. 
According to Hanafie (2010), farmers will always look for ways to allocate inputs as efficiently as possible to obtain maximum production. This is because farmers try to get the maximum profit (profit maximization). When farmers are faced with cost limitations in carrying out their farming business, farmers will still strive to maximize profits by reducing production costs as much as possible. Furthermore, Soekartawi (1993) stated that small farmers usually take the cost minimization approach because they face cost constraints. Small farmers can still increase their profits by reducing the cost of their farming efforts. Ryschawy et al. (2012) study results say that the crop-livestock mix system ensures the farm's financial security in minimizing costs.

Revenue is the gross income received by pond farmers in their business activities. Receipts are the multiplication of the amount of production by the price of production. The gross income received by pond farmers, according to Table 1, shows that the income from milkfish farming still dominates the income of pond farmers. Hanafie (2010) suggests that farmers conduct economic and financial calculations. The choice of production factors is taken into account for profit and loss, whichever is most profitable. Farmers indirectly compare the results expected to be received at harvest time (receipts or revenue) with all the costs to be incurred (sacrifices or costs).

The income of pond farmers consists of income from milkfish farming and dragon fruit farming income. The income earned from milkfish farming is the primary income of pond farmers. Faiq et al (2012), in their research, stated that the payment of milkfish cultivation in Tugurejo Subdistrict, Tugu District, Semarang City on average is IDR2.865.703 per season of a middle land area of 2.69 ha. In his research, Limi (2020) stated that milkfish cultivation with the traditional system in Konawe Regency is the primary source of income that supports the welfare of milkfish farmer families, with production and revenue relatively similar to the traditional cultural system in Indonesia with an average display. $525 \mathrm{~kg} / \mathrm{ha}$ and an average income of IDR6.629.945 with an RC ratio of 5.8 are higher because farmers rely on natural feed as the primary source of milkfish to minimize production costs. Milkfish production can be improved by improving the cultivation system from the traditional method to an intensive system cultivation system. Indra \& Susilo J (2017) stated in their research that the average net income of non-intensive milkfish farming in Manyak Paid District is IDR5.809.315.48 per UT/Period and IDR4.338.971.21 per Ha/Period and intensive which is IDR8.483.598.94- per UT/Period and IDR6.042.300.43,- per Ha/Period.

Furthermore, Limi et al, (2020) stated that the economic aspect includes the average income from milkfish farmers around the Bay of Kendari City of IDR8.303.972/season. The payment will be better if milkfish farmers perform cultivation techniques efficiently. Faiq et al. (2012) the average income of cultivated milkfish is IDR2.865.703 per season with a middle land area of 2.69 ha.

Dragon fruit cultivation is an activity carried out by pond farmers to get added value from pond management. The amount of income obtained from the cultivation of dragon fruit according to Table 1 is IDR1.890.000,- or $15 \%$ of the total income of pond farmers. The payment of pond farmers from dragon fruit cultivation is relatively tiny apart from the narrow land and the high salinity of the soil. Naher et al. (2011) stated that around 53\% are affected by different degrees of salinity in coastal areas in Bangladesh. Land preparation for crop production becomes very difficult as the soil dries, cracks, and the soil surface becomes very hard. So this study recommends increasing soil fertility. To improve soil fertility needs to receive special treatment because of its effect on income. The results of Alwi and Marwah (2015) stated that the results of the study of land-use models in the Wanggu watershed period 1992-2013 generally do not match the ability of land and agrotechnology, as a result of the impact on land degradation in the form of decreased land quality and hydrology of the Wanggu watershed resulting in low farmers' income. sufficient for the necessities of life worth) amounting to IDR22.000.000/year/KK.

The income earned by pond farmers from the cultivation of milkfish is five times greater than the income earned from the cultivation of dragon fruit crops. But the income earned from the cultivation of dragon fruit crops can still be increased. This is because the land utilization of the pond embankment has not been maximized. The planting distance of dragon fruit plants is still relatively rare, so there is still room to plant dragon fruit plants among them. The desire to expand the pond business can be seen to gain added value by cultivating dragon fruit. Maximizing land use can provide increased income. The income of pond farmers increases with the additional income earned from dragon fruit crops. Fyka et al. (2020) found that $40 \%$ of farmers who applied the integrase system of rice farming and cattle income were higher than the UMP and categorized Sejahtera. Activities to maximize land use can increase the income of pond farmers. The added value obtained by utilizing the marginal land of the pond is calculated using the Hayami formula. The results of calculations using the Hayami method can be seen in Table 2. 
Table 3. Results of calculation of pond value added in a year following the Hayami Method (Hayami et al. 1987)

\begin{tabular}{lr}
\hline \multicolumn{1}{c}{ Variable } & Count Results \\
\hline Output, Input, and Price & 571 \\
Milkfish production (kg) & 0,7 \\
Milkfish seeds (1 package = 1.000 fish) & 3 \\
Workforce (org) & 815,7142857 \\
Conversion factor & 4,285714286 \\
Labor Coefficient & 25.000 \\
Milkfish Production Price (IDR/kg) & 1.500 .000 \\
Labor wages (IDR/persons) & \\
\hline Receipts and Profits & 1.200 .000 \\
Price of milkfish seeds (IDR/kg 1 package = 1.000 fish) & 1.890 .000 \\
Other input contribution (Dragon fruit cultivation) IDR/kg & $20.392 .857,14$ \\
Milkfish Production Value (IDR/kg) & $17.302 .857,14$ \\
Value-added (IDR/kg) & 0,848476357 \\
Value Added Ratio (\%) & $6.428 .571,429$ \\
Labor compensation (IDR/kg) & 0,371532365 \\
Labor share (\%) & $10.874 .285,71$ \\
Profit (IDR/kg) & 0,628467635 \\
Profit rate (\%) & \\
\hline In return for production factor services & $19.192 .857,14$ \\
Margin (IDR/kg) & 0,334946036 \\
Labor compensation (\%) & 0,098474135 \\
Contribution of other inputs from dragon fruit cultivation (\%) & 0,566579829 \\
Capital owner profit (\%) & \\
\hline
\end{tabular}

Based on the calculation of Hayami method from the output value of milkfish production as much as $571 \mathrm{~kg}$ and using 1000 fish seedlings weighing $0.7 \mathrm{~kg}$ and using three workers with labor wages IDR1.500.000,- and production price IDR25.000/kg obtained results production of IDR20.392.857,- with the added value obtained of IDR17.302.857,- which gave a profit of IDR10.874.285. As for production value, added value and profit can be seen in Figures 1 and 2.

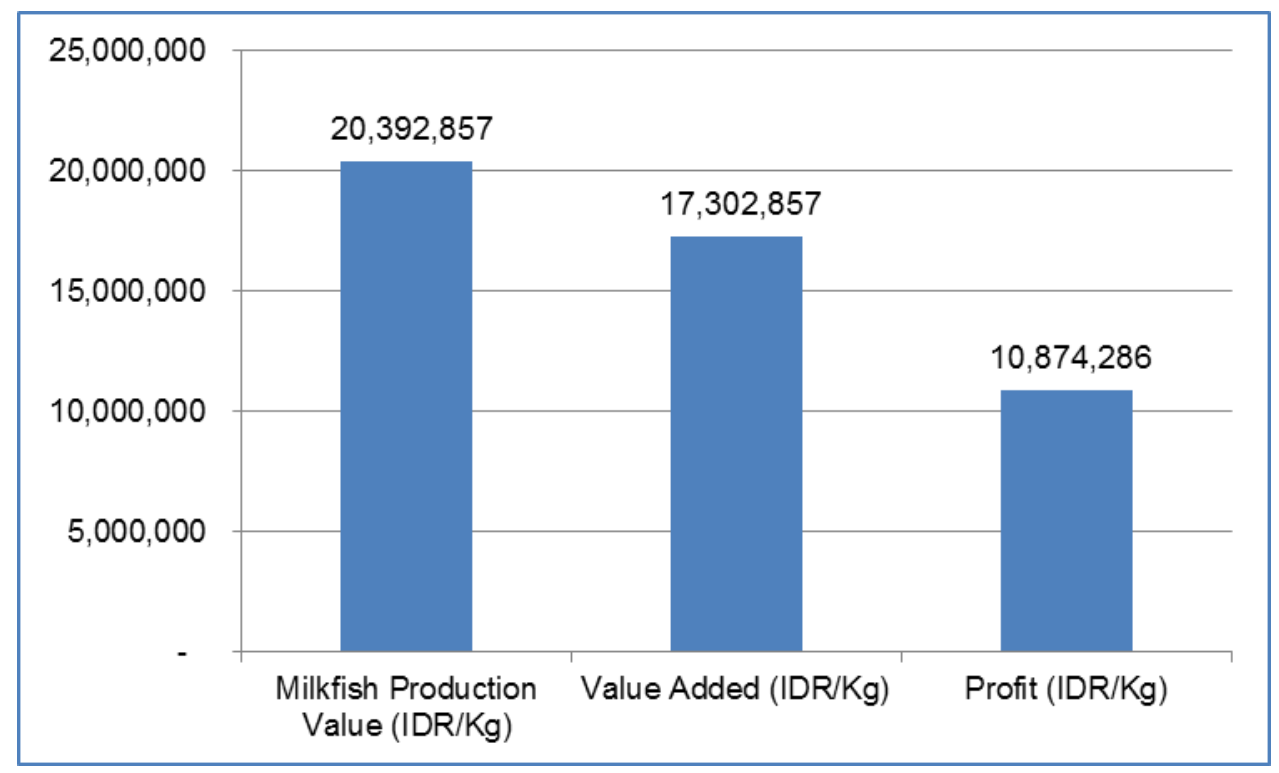

Figure 1. Production value, added value, and benefits of pond management in Wisata Agribisnis

The percentage of profit rate obtained from the pond management in Wisata Agribisnis is at $62 \%$. This figure is relatively high because the profit rate obtained is above $50 \%$, even with a subsistence management system in marginal lands due to the pond's condition, which has experienced shallowness, pollution of household and industrial waste, where the position of the pond is in Kendari Bay. Kamisi (2011) stated that the production of cassava crackers could provide the 
added value of IDR4.044.2/ $\mathrm{kg}$ with a value-added ratio of $0.61 \%$ of the production value. The value of the profit rate and the value-added ratio can be seen in Figure 2.

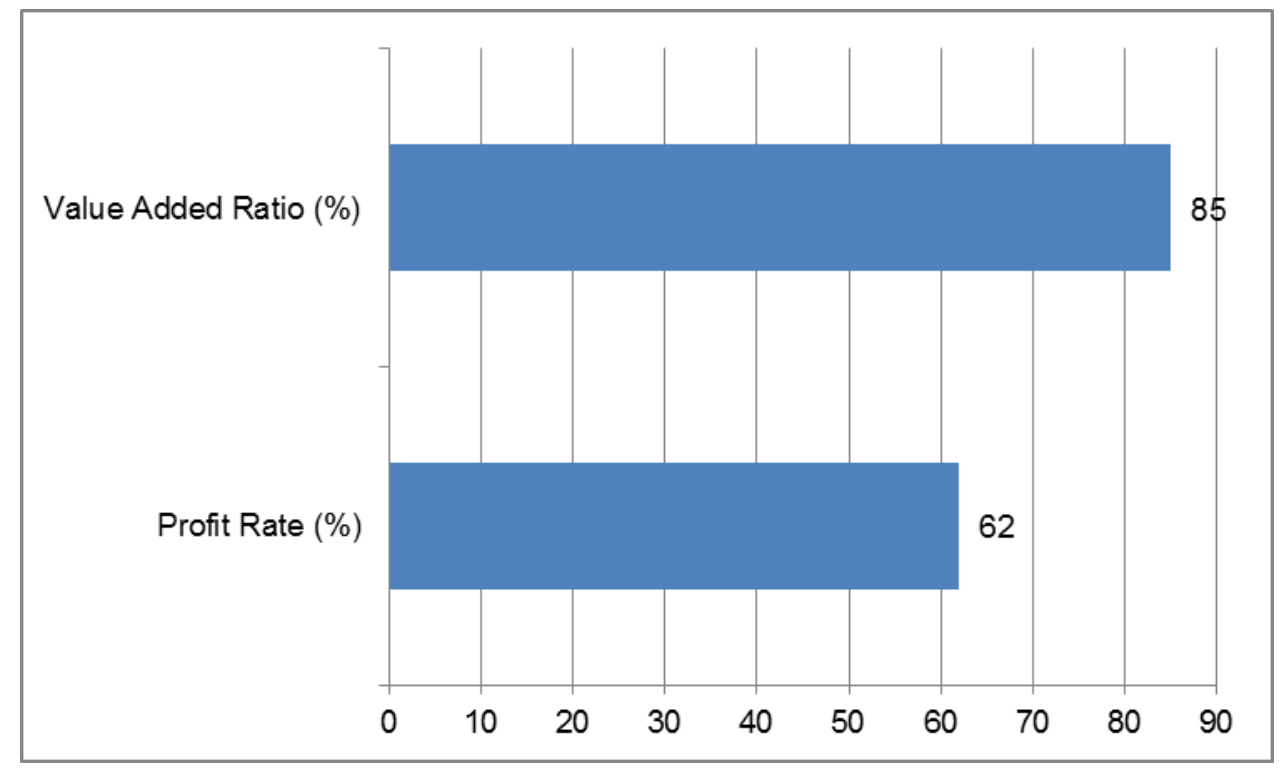

Figure 2. Percentage of profit rate and the value-added ratio of pond management in Wisata Agribisnis

Using the Hayami method and knowing the value-added ratio, it is also possible to see the percentage of profit obtained by capital owners. The value-added ratio of ponds in Wisata Agribisnis is $85 \%$. Sulaiman and Natawidjaja (2018) stated that the average value-added in cassava chips' business is IDR5.232.18 per kilogram with a value-added ratio to the average output value of $23.76 \%$ per production process. This value-added ratio is included in the medium category because it is between $15-40 \%$ based on Hubeis' statement. The benefits of capital owners can be seen in Figure 3.

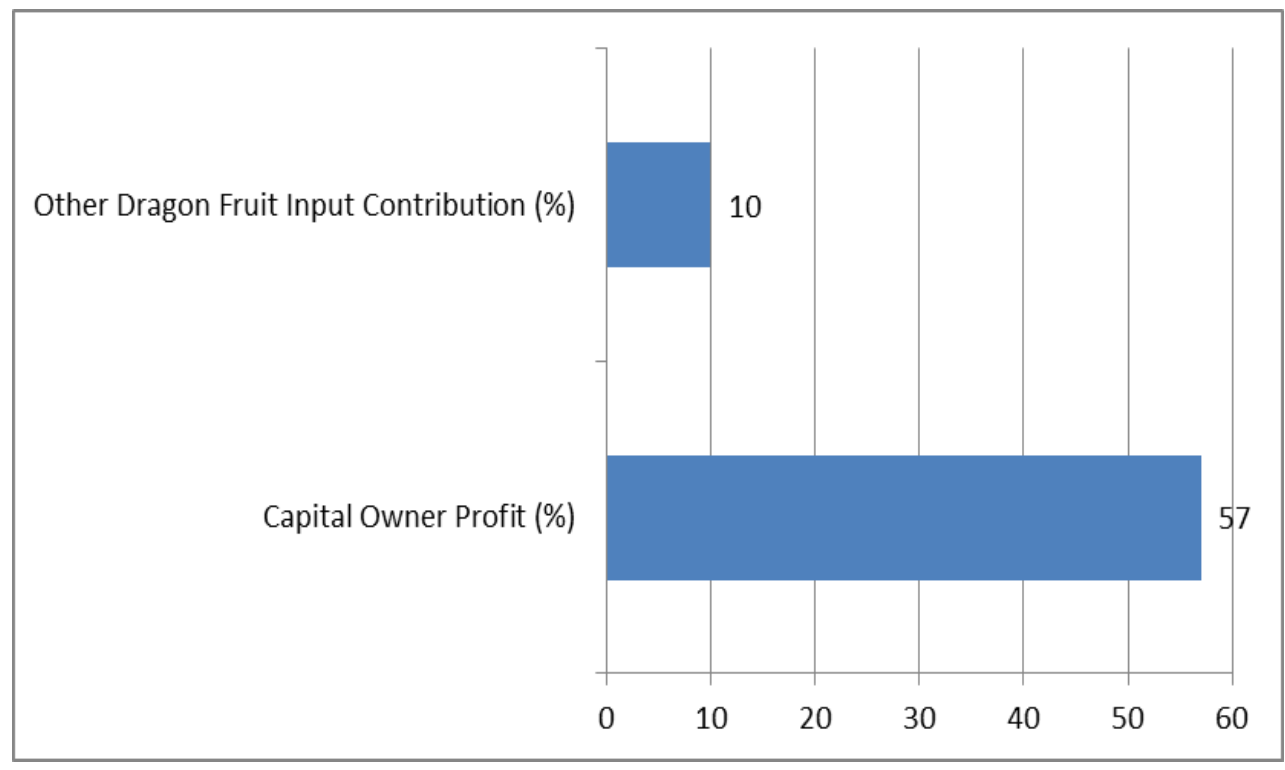

Figure 3. Percentage of profit rate and the value-added ratio of pond management in Wisata Agribisnis

Analysis using Hayami method calculation found that the contribution of other inputs, in this case, the cultivation of dragon fruit plants, contributed $10 \%$ with a profit obtained by capital owners of $57 \%$. Hayami method calculation complements the income analysis calculation model to determine 
the value-added ratio of pond management. The results showed that the planting of dragon fruit in the marginal land of the pond showed: 1) dragon fruit plants do not pollute the pond water, this is because the structure of dragon fruit plants is similar to cactus plants, 2) full sunlight in the pond is very suitable for dragon fruit plants, 3 ) dragon fruit plants are very tolerant of brackish water, 4) the taste of dragon fruit remains sweet in rooting conditions close to brackish water, 5) dragon fruit plants remain dense fruit even when planted in the marginal land of the pond. Cultivation of dragon fruit through the utilization of gorge land is a way to increase the income of pond farmers. In connection with this, research that aims to increase revenue through increased production using efficiency was conducted by Suharno, et al. (2017) that traditional milkfish cultivation in Cilacap has been going on for many years. However, production efficiency is still at a moderate level or 85.20 percent (inefficient). This inefficiency is caused by the inefficient utilization of resources and potential inputs to increase production. As a result, $51.865 .06 \mathrm{~kg}$ per season or IDR471.920.000 of milkfish production was lost.

\section{CONCLUSIONS}

Pond farmers make maximum use of their pond land by cultivating milkfish and planting dragon fruit crops on the pond embankment. Pond farmers earn income from milkfish farming and additional revenue from dragon fruit crops by $10 \%$. The extra income from planting dragon fruit is the added value obtained by the dam farmers in maximizing the use of the dam land with a value-added ratio of $85 \%$.

\section{ACKNOWLEDGMENTS}

Thanks are expressed to the Ministry of Education and Culture for the grant funds provided through PPUPIK. This research can be carried out in Wisata Agribisnis, which designs pond embankments by planting dragon fruit plants through marginal land utilization as a form of technology application.

\section{REFERENCES}

Alwi, L.O., \& Marwah, S. (2015). Analisis dampak perubahan penggunaan lahan terhadap degradasi lahan dan pendapatan petani di das wanggu sulawesi tenggara. Jurnal Pengkajian dan Pengembangan Teknologi Pertanian 18(2):117-130

Faiq, H., Hastuti, D., \& Sasongko, L.A. (2012). Analisis pendapatan budidaya bandeng Kelurahan Tugurejo Kecamatan Tugu Kota Semarang. Mediagro 8(1):72-85

Fyka, S.A., Bahari, Limi, M.A., Salamah., \& Fitriaman. (2020). The welfare level of farmers in the implementation of integration system of farming rice and beef cattle in small household scale in buke sub-district, south konawe district. Buletin Penelitian Sosial Ekonomi Pertanian Fakultas Pertanian Universitas Haluoleo. http://ojs.uho.ac.id/index.php/sosek.doi: http://dx.doi.org/10.37149/sosek.v22i1.12063 . 22(1):7-11

Hartati (2015) Model Sistem Integrasi Usaha Ternak Ayam Pedaging-Itik Manila (entok) di Kabupaten Konawe Selatan. Prosiding. Seminar Nasional "Ketahanan dan Kedaulatan Pangan Berbasis Sumberdaya Lokal' Kerjasama Perhepi Komda Kendari-UHO, 12 Januari 2015 Kendari. ISBN: 978-602-8161-75-6. ppProsiding. 96-106

Hartati., Nuryadi, A.M., \& Husain, H. (2018). Model Diversifikasi Budidaya Ikan Nila Mujair Organik Sebagai Wisata Pemancingan Di Kota Kendari. Prosiding Seminar Nasional Pangan Dan Perkebunan: Realitas Pangan Dan Perkebunan Saat Ini Dan Prospeknya Menuju Swasembada Berkelanjutan. -Kendari, 12 Maret 2018. - Penerbit: UhoHO Edupress, Kendari (2020) • ISBN 978-623-91098-4-4 • Doi Http://Dx.Doi.Org/10.37149/11328. 31-36

Hartati., Padagaran, A.M., Bafadal, A., Bahari, Muhlis, A.M., Nur, M., \& Rosmalah, S. (2017). The Business Modals For Broiler Production in South Konawe Regency of South-East Sulawesi Province, Indonesia. Abah Bioflux, 9(1):28-36

Hayami, Y. et al. (1987). Agricultural marketing and processing in upland Java. A perspective from a Sunda village. CGPRT Centre. Bogor

Indra, S.B., \& Susilo, J. (2017). Perbedaan pendapatan usaha budidaya ikan bandeng (cChanos chanos) intensif dan non intensif di Kecamatan Manyak Payed Kabupaten Aceh Tamiang, Agrisamudra, Jurnal Penelitian, 4(2):57-66

Kamisi, H.L. (2011). Analisis Usaha Dan Nilai Tambah Agroindustri Kerupuk Singkong. Jurnal Ilmiah Agribisnis Dan Perikanan (Agrikan Ummu-Ternate), 4(2):82-87 
Limi, M.A. (2020). The analysis of production and income of milkfish cultivation in north konawe district. Buletin Penelitian Sosial Ekonomi Pertanian Fakultas Pertanian Universitas Haluoleo. 22(1):1-6. http://ojs.uho.ac.id/index.php/sosek

doi: http://dx.doi.org/10.33772/sosek.v22i1.10879

Limi, M.A., La Sara., La Ola T., Yunus L., Surni, Dirgantoro, M.A., Gafaruddin, A., Fyka, S. A., Batoa, H., \& Yusuf, E. A. A., (2020). Technical and economical analysis of milkfish farming on the coastal area of Kendari Bay after sedimentation. AACL Bioflux. 13(1):403-413.

Malini, H., \& Oktarina, S. (2014). Analisis Keuntungan Dan Nilai Tambah (Added Value) Pengolahan Kerupuk Udang dan Pemasarannya Di Sungsang I Kecamatan Banyuasin II Kabupaten Banyuasin Sumatera Selatan. Advantages and Added Value Analysis and The marketing of Prawn Crackers Processing In Sungsang I Banyuasin II Districts, Banyuasin RegencySouth Sumatra. Prosiding Seminar Nasional Lahan Suboptimal 2014, Palembang 26-27 September 2014. ISBN : 979-587-529-9. (45-1)-(45-11)

Manulang, M. (1990). Dasar-Dasar Manajemen. Jakarta: Galia Indonesia. Jakarta

Mubyarto. (1995). Pengantar Ekonomi Pertanian. Penerbit LP3ES. Jakarta

Naher, N., Uddin, M.K., \& Alam, A. K. M. M. (2011). Impacts of salinity on soil properties of coastal areas in bangladesh, Agivita. 33(2):161-173

Padangaran, A.M. (2013). Analisis Kuantitatif Pembiayaan Perusahaan Pertanian. IPB Press. ISBN: 978-979-493-547-7. Bogor

Ryschawy, J., N. Choisis, N., J. P. Choisis, J. P., A. Joanno, A., \& A. Gibon, A. (2012). Mixed croplivestock systems: an economic and environmental-friendly way of farming. Animal \& The Animal Consortium. doi:10.1017/S1751731112000675, 6(10):1722-1730

Samuelson, P.A. \& Nordhaus,. W.A. (2004). Mikro Ekonomi. Penerbit Erlangga. Jakarta

Siagian, R. (2009). Manajemen Agribisnis. Gadjah Mada University Press. Yogyakarta

Soekartawi., A. Soeharjo, A., Dillon, J.L., \& Hardaker, J.B. (1986). Ilmu Usahatani dan Penelitian untuk pengembangan Petani Kecil. UI Press. Jakarta.

Soekartawi., Soeharjo, A., Dillon, J.L., \& Hardaker, J.B. (1993). Prinsip Dasar Ekonomi Pertanian Teori dan Aplikasi. PT. Raja Granfindo Persada. Jakarta.

Suharno, Susilowati, I., \& Firmansyah. (2017). Management of the traditional milkfish culture in Indonesia: an approach using technical efficiency of the stochastic frontier production. $A A C L$ Bioflux 10(3):578-586.

Sulaiman \& Natawidjaja, R.S. (2018). Analisis Nilai Tambah Agroindustri Keripik Singkong (Studi Kasus Sentra Produksi Keripik Singkong Pedas di Kelurahan Setiamanah, Kecamatan Cimahi Tengah, Kota Cimahi). Jurnal Ilmiah Mahasiswa Agroinfo Galuh, 5(1):973-986 